\begin{tabular}{|c|l|}
\hline Title & Frontiers in Population Ecology of Microtine Rodents : a Pluralistic A pproach to the Study of Population Ecology \\
\hline Author(s) & STENSETH, Nils Chr.; SA ITOH, Takashi; Y OCCOZ, Nigel G. \\
\hline Citation & Researches on population ecology, 40(1), 5-20 \\
\hline Issue Date & 1998 \\
\hline Doc URL & http://hdl.handle.net/2115/16991 \\
\hline Type & article \\
\hline File Information & RPE40-1.pdf \\
\hline
\end{tabular}

Instructions for use 


\title{
Frontiers in Population Ecology of Microtine Rodents: a Pluralistic Approach to the Study of Population Ecology
}

\author{
Nils Chr. Stenseth ${ }^{*}$, ), Takashi SaItoH ${ }^{*, 2)}$ and Nigel G. Yoccoz ${ }^{*, 3)}$ \\ ${ }^{*}$ Centre for Advanced Study, Norwegian Academy of Science and Letters, Drammensveien 78, N-027I Oslo, Norway \\ 1)Division of Zoology, Department of Biology, University of Oslo, P.O. Box 1050 Blindern, N-0316 Oslo, Norway \\ ${ }^{2)}$ Hokkaido Research Center, Forestry and Forest Products Research Institute, Sapporo 062-8516, Japan \\ ${ }^{3)}$ Department of Arctic Ecology, Norwegian Institute for Nature Research, Storgata 25, N-9005 Tromsø, Norway
}

\begin{abstract}
Current challenges for the study of population ecology of microtine rodents are reviewed. Comparisons with other taxonomic groups (other mammals, birds and insects) are given throughout. A major challenge is to link patterns and processes (i.e. mechanisms) better than is the case today. Other major challenges include the furthering of our understanding of the interaction between deterministic and stochastic processes, and as part thereof, the interaction between density-dependent and density-independent processes. The applicability of comparative studies on populations exhibiting different temporal dynamical patterns is, in this connection, emphasized. Understanding spatiotemporal dynamical patterns is another major challenge, not the least from a methodological point of view. Long-term and large-scale ecological data on population dynamics (in space and time) are critical for this purpose. Looking for consistency between hypothesized mechanisms and observed patterns is emphasized as a good platform for further empirical and theoretical work. The intellectual feedback process between different approaches to the study of microtine population ecology (observational studies, experimental manipulative studies, statistical modeling and mathematical modeling) are discussed. We recommend a pluralistic approach (involving both observational and experimental as well as theoretical studies) to the study of small rodent ecology.
\end{abstract}

Key words: Clethrionomys rufocanus, experimental manipulation and testing, mathematical modeling, patterns and processes, statistical modeling.

\section{Introduction}

"let's do something on mice" (C. S. Elton 1925; cited from Crowcroft 1991: 6)

Elton (1924) identified the scientific problem of periodic fluctuations in northern microtine rodents. This topic naturally became one of the key issues focused upon in his institute, Bureau of Animal Population at Oxford (Crowcroft 1991). Elton's original interest in the phenomenon of periodic fluctuations in microtine rodents (Arvicolinae) started after becoming aware of already published data on the dramatic fluctuations in the Norwegian lemmings (Lemmus lemmus; Collett 1911-12; see

1) E-mail: n.c.stenseth@bio.uio.no

2)E-mail: bedford@ffpri-hkd.affrc.go.jp

3)E-mail: nigel.yoccoz@ninatos.ninaniku.no also Stenseth and Ims 1993a; Stenseth 1995a) - data emerging from the 'collecting-tradition' dominating among the Fennoscandian naturalists (see Hansson and Stenseth 1988).

Today we know that the dramatic fluctuations in abundance seen in many northern microtines are periodic - that is, we know that the so-called 'microtine cycle' is real (e.g. Stenseth and Ims 1993b). The causes underlying these periodic fluctuations continue to be debated, though (cf. Lidicker 1988, 1991; Gaines et al. 1991; Batzli 1996; Krebs 1996). Indeed, why some microtines exhibit periodic multiannual fluctuations in parts of their geographic range of distribution whereas they do not in other parts (Hansson and Henttonen 1985; Henttonen et al. 1985; Hansson and Henttonen 1988), is one of the central puzzles within the field of ecology.

There are essentially two broad approaches to the study of the 'microtine cycle': the 'time series tradition' (focus- 
ing on the pattern of temporal variation in abundance and effectively started by Charles Elton with his book "Voles, mice and lemmings"; Elton 1942; for a recent analysis of part of Elton's data, see, Ranta and Kaitala 1997; Ranta et al. 1997) and the 'experimental tradition' (focusing on processes and advocated most strongly by Charles Krebs and his many students; e.g. Krebs and Myers 1974; Taitt and Krebs 1985). The former was referred to as the 'watch-and-count, wait-and-hope approach' by Krebs (1997), whereas the latter was called the 'muck-aboutwith-something approach' (Fig. 1). Both approaches have generated valuable insights into the population ecology of microtine rodents specifically, and into ecology in general (for reviews, e.g. Cockburn 1988; Stenseth and Ims 1993c). Unfortunately, there has been too little effort directed towards synthesizing these two approaches and hence to integrate the insights derived. To do so, is indeed a challenge.

Even though microtine rodents are quite secretive, they are relatively easy to trap in the field as well as to keep in the laboratory. They are also good experimental organisms at the individual and population levels - be it in the laboratory (e.g. Gustafsson 1985; Hansson 1987; Ims 1994, 1997) or in the field (Taitt and Krebs 1985; Ims 1988). The fact that several species also have populations with greatly different population dynamic patterns (Hansson and Henttonen 1988), renders microtine rodents a most interesting group of study organisms.

In this introductory paper to the Special Feature of Researches on Population Ecology on 'The Population Ecology of the Vole Clethrionomys rufocanus', we outline some of the main approaches to the study of fluctuations in microtine rodents; as an integral part of our discussion, we also outline the major frontiers and challenges within this field of ecology.

\section{Temporal fluctuations in abundance of animal populations}

\begin{abstract}
"Ecology is the scientific study of the interactions that determine the distribution and abundance of organisms" (C. J. Krebs 1994:3)
\end{abstract}

\section{The patterns and possible causal mechanisms}

Essentially all microtine rodents exhibit seasonal fluctuations in abundance. Even though microtine rodents are best known for their multiannual density fluctuations (e.g. Finerty 1980; Lidicker 1988; Stenseth and Ims 1993a, b), several of them do not exhibit such cycles in any part of their geographic range of distribution (at least as is thus far known; e.g. Finerty 1980; Stenseth and Ims 1993b). Only about ten species are known to exhibit periodic density fluctuations in at least parts of their range of distribution - Clethrionomys rufocanus is one of them (Stenseth et al. 1996a; Bjørnstad et al. 1998a, b; Saitoh et al. 1998b). For Fennoscandia and the northernmost island of Japan, Hokkaido, there are particularly good data on the spatial variation in the temporal dynamics of microtine rodents. In Fennoscandia we know that microtine rodents exhibit periodic multiannual fluctuations at high latitude (broadly
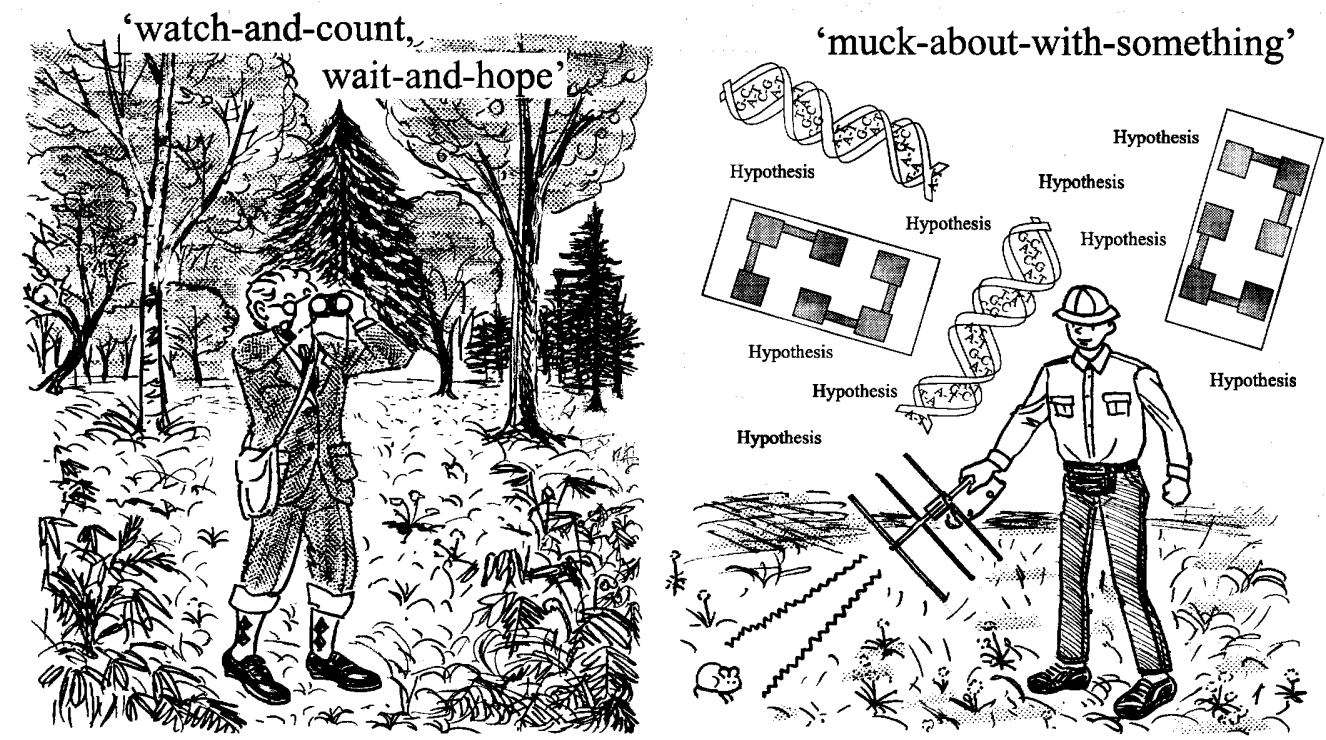

Fig. 1. Two representative approaches in studies of the 'microtine cycle': Charles Krebs (1997) called the time-series tradition as the 'watch-and-count, wait-and-hope approach' and the experimental tradition as the 'muck-about-with-something approach' (illustrated by H. Honma). 
speaking, north of $60^{\circ} \mathrm{N}$; cf. Hansson and Henttonen 1988; Hanski et al. 1991, 1993; Bjørnstad et al. 1995; Stenseth et al. 1996b; further south, only seasonal fluctuations have been observed; Hansson 1971). Proceeding towards the north, the intervals between peaks (i.e. the period of the regular fluctuations) increase from about three years to five years. The amplitude also tends to increase with latitude. In Hokkaido a similar pattern exists: in the southern and western parts of the island the fluctuations tend to be only seasonal whereas north and east there are multiannual periodic fluctuations (e.g. Bjørnstad et al. 1998b; Saitoh et al. 1998b).

For other parts of the world, much less information on the geographic pattern of temporal fluctuations in microtine rodents is available. It is, however, clear that periodic fluctuations in abundance of microtine rodents do occur in North America (e.g. Finerty 1980; Pitelka and Batzli 1993), Greenland (Sittler 1995) and Siberia (Gromov and Polyakov 1992).

Other mammal species are also known to exhibit population cycles resembling those seen among microtine rodents (see Elton 1942; Finerty 1980): snowshoe hares, lynx and fox also show such periodic fluctuations (see, e.g. Krebs et al. 1995; Stenseth 1995b). Other groups of animals are also known to fluctuate periodically: some birds exhibit such cycles (particularly capercaillie and grouse; Lindén 1988; Moss et al. 1996). Although many insect populations fluctuate greatly, most of them are aperiodical (Itô 1968, 1978); only a few forest insects exhibit periodic fluctuations (e.g. Myers 1988; Haukioja et al. 1988; Liebhold et al. 1996).

Much work has been devoted to the search for the underlying mechanisms of these fluctuations, but agreement is not yet reached (Krebs 1996). For several decades, phenotypic and genotypic differences between individuals in different cyclic phases (e.g. increase, peak and decline phases) were emphasized (Christian 1950, 1980; Chitty 1960, 1967; Krebs and Myers 1974; Stenseth 1977a, 1981, 1985a, 1986; Krebs 1978; Charnov and Finerty 1980; Hestbeck 1982; Warkowska-Dratnal and Stenseth 1985; Stenseth and Komnicki 1990). The main argument is that there are qualitative changes in the population through the cycles, which are best described using discrete, step-functions. This view on periodically fluctuating populations is one example of what Framstad et al. (1997) called phasedependence. The notion of phase-dependency is generally not found within the literature on most other animal groups, for instance large mammals, birds or insects, for which the question of population regulation through density-dependence has received more attention (Lack 1954; Itô 1978; Sinclair 1989; Hanski 1990; Messier 1991; Woiwod and Hanski 1992; Murdoch 1994; Cappuccino and Price 1995; Turchin 1995a; Sinclair and Pech 1996). Such a view emphasizes continuous changes with respect to density, usually assuming there are no qualitative changes through the cycle. A combined view of phaseand density-dependence may hold a key to the understanding of periodically fluctuating microtines (Stenseth et al. 1998a).

Experimental studies aiming at testing several of the proposed hypotheses relating to the underlying mechanisms for observed population fluctuations have provided much information needed to understand the biology of rodents. Recently, the observational tradition has become more popular because of a renewed interest in time series analyses of ecological data (e.g. Royama 1992). Although Krebs (1991), among others, criticized the analyses of density-dependence using time series "because no mechanisms are specified", he recently evaluated the time series studies on the Hokkaidian Clethrionomys rufocanus data and concluded that these data "provide an opportunity for small-rodents ecologists to merge together pattern studies via time-series analysis and process studies of mechanisms of population regulation" (Krebs 1997).

The issues of temporal pattern in space are discussed in what follows by Saitoh et al. (1998b), Bjørnstad et al. (1998b; see also Bjørnstad et al. 1998a) and Stenseth et al. (1998b). Underlying mechanisms are discussed by Ishibashi et al. (1998a, b; see also Yoccoz et al. 1998). Bjørnstad et al. (1998b) analyzed the periodic behavior (the spectral density functions of the growth rates) using extended data-sets covering the entire island of Hokkaido. They showed a clear transition from relatively stable populations in the southwest and west to populations undergoing 3-4 year cycles in the northeast and east of the island. The degree of seasonality in the vegetation and rodent demography appeared to be stronger in the cyclic area (see also Stenseth et al. 1998b).

\section{The classic controversy of population regulation}

The field of ecology has long been troubled by the controversy over how populations are regulated (Nicholson 1933, 1954; Andrewartha and Birch 1954; see also den Boer and Reddingius 1996). Mostly, this controversy has centered on the commonness of density-dependence (Hanski 1990; Turchin 1990; Holyoak 1994) and the role of density-dependence in population dynamics (Strong 1986; Stiling 1988; Hassell et al. 1989; Berryman 1991, 1992; den Boer 1991; Grenfell et al. 1992; Hörnfeldt 1994; Saitoh et al. 1997; Sæther 1997).

Essentially, there are two approaches for analyzing density-dependence: 1) studying direct relationships between life history parameters and density, for example, with capture-recapture studies (Pollock et al. 1990; Lebreton et al. 1992; Leirs et al. 1997; see also Ostfeld et al. 1993; Ostfeld and Canham 1995), and 2) searching for statistical density-dependence in time series data on population 
abundances (Crowley 1992; Royama 1992). The time series approach has become quite popular for small rodents (e.g. Hörnfeldt 1994; Saucy 1994; Bjørnstad et al. 1995; Stenseth et al. 1996a, b; Saitoh et al. 1997, 1998a, b). These studies show convincingly the existence of densitydependence, which is not the case for the more 'noisy' insect time series (e.g. Woiwod and Hanski 1992; Turchin 1995a) where very high sampling variation may obscure any density-dependent patterns.

Large mammals have provided what could arguably be said to be the best evidence for the ecological mechanisms leading to direct and delayed density-dependence. In addition, the interaction between density-dependent and density-independent factors has been understood quite clearly for some species of large mammals (e.g. Sauer and Boyce 1983; Clutton-Brock et al. 1985, 1991, 1997; Albon et al. 1987; Messier 1991; Gaillard et al. 1993; Portier et al. 1998; see reviews by Sæther 1997 and Gaillard et al. 1998). Most of these studies have focused on demographic processes without relying on time series analysis. The impact of density as well as density-independent factors such as rainfall or temperature on demographic parameters follow a well-defined sequence: reproductive/recruitment parameters such as age at first reproduction or juvenile survival appear to be affected first, whereas adult survival and longevity are affected last (Eberhardt 1977; Gaillard et al. 1998). Small mammals may show a reverse sequence, but there are too few studies where all demographic parameters have been properly estimated so as to reach a definitive conclusion (Gaillard and Yoccoz 1998). This will provide an exciting area of investigation in the years to come.

\section{Mechanisms and prevalence of direct density- dependence}

The issue of density-dependence has been extensively studied in the gray-sided vole of Hokkaido, Japan (Clethrionomys rufocanus; Saitoh et al. 1997, 1998a, b): direct density-dependence is commonly found. This species is known to have strong social suppression of various demographic rates which may be a plausible mechanism underlying the direct density-dependence. Territoriality, for instance, typically brings about delayed maturation during periods of high density (Kalela 1957; Abe 1976; Saitoh 1981, 1991; Nakata 1989). Similar density effects are known among other congeners (C. glareolus: Bujalska 1970; C. gapperi: Bondrup-Nielsen 1986; C. rutilus: Gilbert et al. 1986). Generalist, or highly mobile predators, may also cause such direct density-dependencies.

\section{Delayed density-dependence}

A population with only direct density-dependence will not show multiannual periodic fluctuations with periods as observed in microtine rodents (e.g. Royama 1992). Some sort of delayed density-dependence is needed. Delayed effects may be obtained through a variety of processes (see, e.g. Royama 1992). Among the possible mechanisms which may lead to a delayed density-dependent structure is a specialized trophic interaction (predation or food; see, for example, Stenseth et al. 1996b).

Saitoh et al. (1997, 1998a, b) examined delayed densitydependence in C. rufocanus of Hokkaido. In contrast to direct density-dependence, only a modest fraction of the populations exhibits delayed density-dependence. It is more common in northeastern populations than elsewhere. This geographic gradient is similar to that in cyclicity and temporal variability; the more northeastern populations are more cyclic and more variable. The relationship between delayed density-dependence and cyclicity is also evident in comparison with other rodent species. Wood mouse populations in Hokkaido (Apodemus argenteus and $A$. speciosus) - that are clearly not cyclic do not exhibit delayed density-dependence at all. The difference in the density-dependent structure between Clethrionomys and Apodemus is consistent with the trophic interaction theory for delayed density-dependence that predators have a larger impact and depend more on the gray-sided vole than on wood mouse species (see Saitoh et al. 1998a).

\section{The issue of non-linearity}

May's (1974) pioneering work demonstrating that rather complicated dynamics may arise from simple models provided that they are non-linear and discrete - generated much interest in non-linear dynamics within the field of ecology (see also May 1986). Essentially, two main issues have been targeted:

1) Determining whether a given population exhibits a "chaotic" dynamics. This poses very difficult theoretical - both statistical and mathematical - questions that are yet to be solved (Tong 1995; see also Falck et al. 1995b). It remains unclear what can be learnt about the underlying population dynamics processes, even if we convincingly can conclude that a population exhibits chaotic dynamics.

2) Determining the extent to which underlying mechanisms are non-linear. We favor this approach because it provides more direct insights into the structure of ecological interactions within populations and between populations within a given region.

May's (1974) original paper leads to a widespread search for chaos in population dynamics data (e.g. Hanski et al. 1993; Turchin 1993, 1995a, b, 1996; but see Falck et al. 
1995a, b). Much of the initial enthusiasm for the supposed appearance of chaos in field data, including those on rodents (e.g. Turchin 1993, 1995b), is not without critics (e.g. Falck et al. 1995a, b). How to determine chaos in a stochastic process is, however, a difficult problem (Paladin et al. 1995; Tong 1995; Vulpiani 1995; Loreto et al. 1996). Sugihara (1994) argued that the use of essentially deterministic models in what is essentially a stochastic dynamics situation is 'fundamentally flawed' as a means of detecting chaos.

\section{The importance of stochasticity}

Before the recent focus on chaos, the microtine cycle was generally thought to correspond to some sort of limit cycle (May 1972; Stenseth 1977a, 1985a; Gilbert 1984; Hanski et al. 1991; Framstad et al. 1997). However, for this to be the case, rather strong non-linearity must exist.

However, a log-linear model (i.e. a model that is not really 'non-linear' in the dynamical sense) combined with (additive) environmental stochasticity may produce sustained cycles having many of the features observed in real life populations (Stenseth et al. 1996a). Much more work is needed before we understand the range of population dynamical effects of the interaction between deterministic phase- and density-dependent factors and the stochasticity inherent in population growth (where stochasticity may also be phase-dependent). We presume that such work may provide valuable insights into the population dynamics of periodically fluctuating microtine populations. Stochastic population models have seen significant advances during the last 50 years (e.g. Kendall 1949; Bartlett 1970; Dennis and Patil 1984; Lebreton 1990; Engen and Lande 1996). Stochasticity has, however, to a large extent been ignored as an important factor in population dynamics theory.

Hjellvik and Tjøstheim (1998a, b) have - partly with reference to the Hokkaido time series data on Clethrionomys rufocanus - started developing a methodological platform for studying the relative importance of different types of local and regional stochastic factors in an autoregressive setting. Much more remains to be done and is in progress. Biological interpretation of these methodological studies remains to be done.

\section{Spatial structure and scale}

\footnotetext{
"To understand the drama, we must view it on the appropriate scale" (J. A. Wiens 1989: 385)
}

Stacy et al. (1997) observed geographic differentiation of mtDNA haplotypes along a linear transect spanning $256 \mathrm{~km}$ in the Scandinavian population of the bank vole
(Clethrionomys glareolus). Because the probability of gene identity rapidly declines, they concluded that a local population does not extend over areas larger than $8.5 \mathrm{~km}$. This scale may reflect the range of gene flow based on accumulated effects of female dispersal, but is not consistent with the geographic scale (at least $30-40 \mathrm{~km}$ ) in synchrony of population fluctuation (Steen et al. 1996). Thus, external factors (e.g. mobile predators) seem to be required for the synchrony (Stacy et al. 1997).

Bjørnstad et al. (1998a) report on the spatial correlation in population dynamics of the gray-sided vole (C. rufocanus) using 185 time series spanning 31 years (1962-1992) from northernmost part of Hokkaido. The similarity in population dynamics dropped with distance, as expected. The spatial scale of the pattern of fluctuations was defined as the distance at which the similarity is equal to that expected by chance alone in the region. This distance was estimated to be approximately $50 \mathrm{~km}$ for $C$. rufocanus of Hokkaido. This spatial scale was argued to be larger than what can be accounted for by dispersal or other individual-based processes of rodents. Regulation of the vole by predators, and at the scale of predator movement, may be the agent inducing the correlation. This suggestion needs to be experimentally tested.

The analyses above suggest that some important dynamical processes occur at scales much larger than the classical scale of population studies (most of the time ca. $1 \mathrm{ha}$ ). Population dynamics in a given area is the result of the interaction between local processes such as direct effects of density on reproductive rates and more regional processes such as movements and dispersal of avian predators (e.g. Ims and Steen 1990). Understanding the relative importance of local and regional processes acting at different scales necessitates that we are first able to identify the appropriate scales (Wiens 1989). This has now been done for coarse grained processes, but there remains much to be done at the small-scale level. Indeed, because the spatial scale of sampling should be at least half of the scale of spatial autocorrelation (Sokal and Oden 1978; Epperson and Li 1997), phenomena occurring within the 0.1$10 \mathrm{~km}$ range have mostly not been described. The extent of dispersal distances, for example, is still very much unknown due to the small scale of most studies, and may be expected to affect population dynamics within this scale range. Microtines may move extensively, up to a few kilometers (Steen 1994; the extreme case is provided by the lemming migrations observed in Fennoscandia; Henttonen and Kaikusalo 1993). How such dispersal movements interact with population dynamics and at what scale, is largely unknown. Finally, the spatial patterns of the landscape may strongly affect the importance of such movements, and more generally, population dynamics of small mammals (e.g. Hansson 1979). 
Thus, external factors (e.g. weather factors or mobile predators such as birds of prey) seem to be required for a synchronism at such a scale (Ims and Steen 1990; Stacy et al. 1997). Climatic effects - related for example to depth and duration of snow cover - may also result in spatial patterns at such a scale (or larger); however this has not been studied yet in any detail. Moreover, we could expect that the density-dependent structure of the time series would be different, as predators may respond numerically to density in previous year, while obviously weather would not. The framework developed by Hjellvik and collaborators would be most useful here.

Effects at a very small spatial scale (i.e. within a population) have attracted much interest recently. Animals are unevenly distributed and the range of individual interactions is, so restricted that individuals do not interact with all individuals in a local population. Kawata (1997) suggested on the basis of theoretical considerations that such scale influences the nature of the density-dependent structure. In fact female kin-clusters are found in $C$. rufocanus (Ishibashi et al. 1997). The effects of such a clustering on demography may be quite significant ecologically (Lambin and Krebs 1991, 1993; Lambin and Yoccoz 1998; Ishibashi et al. 1998b).

Synchronization of outbreaks of forest insect populations occur over areas ranging several hundreds up to thousands of km (Tenow 1972; Barbour 1990), and even at the scale of the whole Northern Hemisphere (Myers 1998). For example, the occurrence of outbreak populations of the pine looper (Bupalus piniarius) was significantly correlated across areas spanning about $240-320 \mathrm{~km}$ (Barbour 1990; Klimertzek 1990). Outbreaks of the cyclic autumnal moth (Epirrita autumnata) are usually synchronized over the whole Fennoscandian peninsula (Tenow 1972). The cause of such synchronization is still unclear, but its scale indicates that weather conditions may be responsible for the synchrony (Moran 1953b; Myers 1998; see also Royama 1992).

\section{Challenges within the field of microtine rodent population biology}

"Looking back I think it was more difficult to see what the problems were than to solve them" (C. Darwin; cited from Andrewartha and Birch 1984: 19)

Periodic multiannual fluctuations do occur in some populations whereas only seasonal fluctuations occur in others (Hansson and Henttonen 1988). It remains a challenge to understand and explain this phenomenon. The Hokkaido data are ideally suited as an empirical platform for searching for such explanations because some populations are clearly cyclic whereas others are not (Bjørnstad et al. 1998b; Saitoh et al. 1998b).

Both density-dependent and density-independent processes operate in real populations (cf. Turchin 1995a). Understanding the mechanisms underlying density-dependent and density-independent patterns remain unclear - even though some sort of social interaction (leading to, e.g. territoriality and delayed maturation) are relevant for generating the density-dependence observed in the time series. Observational and experimental studies of the kind reported by Ishibashi et al. (1998a, b) seem to be important for this purpose; populations of Clethrionomys rufocanus in Hokkaido are good candidates for such studies because density-dependent patterns in population dynamics prevail (Saitoh et al. 1997, 1998a, b).

Among the cyclic populations delayed density-dependence is observed. What the underlying processes are, remain unclear. Some sort of specialized trophic interaction processes may be responsible for the observed delayed density-dependence (cf. Royama 1992; Stenseth et al. 1996b). Due to the fact that C. rufocanus in Hokkaido includes populations both with and without delayed density-dependence, further experimental work involving food and predators may be profitable. Such experimental work should pay attention to the scale of the experimental treatments (see, e.g. Stenseth and Ims 1993b).

An important challenge is to understand how stochastic processes (e.g. weather) interact with deterministic processes (see, e.g. Leirs et al. 1997). The Hokkaido $C$. rufocanus is ideal for such investigations because different parts of the island are influenced by different climatic regimes (see, e.g. Saitoh et al. 1998b: Fig. 1).

An almost virgin field is the empirical study of the interaction between temporal processes (in any given population) and spatial interdependencies between populations (both direct through dispersal as well as indirect through migrating and nomadic predators and regional weather conditions). Several theoretical papers have analyzed some of these processes (e.g. predation: de Roos et al. 1991; dispersal: Ruxton and Doebeli 1996). One set of theoretical predictions relate to the appearance of traveling waves - a dynamical pattern moving at a constant speed while maintaining its shape (e.g. Shigesada and Kawasaki 1997). There is some empirical evidence for the existence of such phenomena (Lambin et al. 1998). The Hokkaido data will, quite likely, serve as a very good platform for such work - be it biological, statistical or mathematical.

An overall challenge is to link population processes both with respect to structure (direct and delayed densitydependence and density-independent patterns) and demographic processes. Further experimental work involving capture-mark-recapture procedures in different locations in Hokkaido using C. rufocanus as an experimental organism may be profitable in this connection (see Yoccoz et 
al. 1998).

These challenges need to be approached using a variety of approaches (cf. Fig. 2). No single approach (i.e. observational, experimental, statistical or mathematical) will be sufficient; a pluralistic approach with close interaction between different traditions such as descriptive time series analysis and experimental (and comparative) empirical work is likely to yield improved insights into questions like "why do some microtine populations exhibit periodic multiannual fluctuations whereas other populations (often of the same species) don't?" In what follows, we review some of these methodological interfaces.

\section{Ecology and statistics meet - again}

\begin{abstract}
"Statistics needs scientists with an intelligent grasp of what they are talking about to keep mathematicians, who have their own uses, on the rails" (R. A. Fisher; cited from Box 1978)
\end{abstract}

Ecological data has long been playing an important role in the development of statistical methods, not the least for the estimation of demographic parameters and population size (reviewed by Lebreton et al. 1992; Seber 1992; see Yoccoz et al. 1998) and analysis of temporal pattern (i.e. time series modeling; Campbell and Walker 1977; Tong 1977). Time series modeling extends back more than three-quarter of a century, when the British statistician Yule (1927) first introduced the class of autoregressive models in his analysis of the cycles apparent in sunspot numbers. As far as applications of time series modeling to ecological data are concerned, the autoregressive approach is dominant. The earliest such application seems to be Moran (1953a, b), who fitted a second order autoregressive model to the logarithmically transformed data on Canadian lynx in the Mackenzie River area. That paper made a profound impact on the biological/ecological literature (see, e.g. Royama 1992). In the statistical literature, his paper also drew the attention of a succession of statisticians, including many prominent time series analysts (for details see, Campbell and Walker 1977; Tong 1977).

Up to the late 1970s, all time series models reported in the statistical literature for ecological population data were linear. The first realization of the need for a radical shift of focus was apparent in the papers by Cambell and Walker (1997) and Tong (1977) at the Royal Statistical Society meeting. During the last few years ecological data have again become of interest to statisticians in the development of new statistical methods (e.g. Ellner and Turchin 1995; Chan et al. 1998a, b; Yao et al. 1998; Hjellvik and Tjøstheim 1998a, b). The data on the voles of Hokkaido discussed in several papers in this Special Feature of Researches on Population Ecology may turn out to become a benchmark data-set, just like the lynx data-set of the Hudson Bay Company have been among statisticians for a long time (e.g. Tong 1990; see also Stenseth et al. 1997, 1998c). The fact that the Hokkaido data consist of many - more or less independent - time series (i.e. panel data) renders them particularly useful in spite of their shortness. Even though chiefly log-linear models have been applied to the Hokkaido data thus far, these panel data may certainly be used for further testing nonlinear models of the kind studied by, for instance, Framstad et al. (1997), Chan et al. (1998a), and Stenseth et al. (1998d).

As biologists, we are not particularly interested in time series models per se (except perhaps for short-term predictions). Nevertheless to ask which underlying population model is consistent with a given statistical model has proven to be a valuable strategy (e.g. Stenseth et al. 1996b). This approach certainly does not yield any proof regarding which underlying process(es) generates the observed time series data. This approach, however, suggests - sometimes very clearly - which mechanisms may be more likely to operate and thus worth further experimental testing. When interpreting statistical results, the order of the process (i.e. the number of lags included in the autoregressive model) suggests the number of interacting components which need be included in the explanation of the observed patterns.

We are now at a point where analyses of time series and demographic processes are sophisticated enough to represent rather complex ecological mechanisms (e.g. phase-dependence as well as direct and delayed densitydependence in time series of population abundances). The link between these two approaches - dynamical and demographical - is, however, missing, except for in the case of some controlled laboratory populations (Dennis et al. 1997; Bjørnstad et al. 1998c). To determine which mechanisms are the most important for determining the dynamical patterns will require such an integration.

\section{Theoretical ecological modeling meets data}

\footnotetext{
"Mathematics without natural history is sterile, but natural history without mathematics is muddled" (J. Maynard Smith 1982)

"Sound naturalism is to ecology what legs are to a runner; but anti-theoretical naturalists are, quite naturally, like headless runners" (Y. Haila and O. Järvinen 1982)
}

The predator-prey models developed and discussed by Lotka (1925) and Volterra (1931) have been much cited in connection with rodent cycles (e.g. May 1972, 1974; Stenseth 1977a, 1985a). Unfortunately, their biological assumptions may not be appropriate for microtine ro- 
dents. These models have nevertheless had a tremendous influence on our thinking of periodically fluctuating populations such as those of the northern microtines.

Recently, more refined predator-prey models have been developed (Hanski et al. 1991, 1993; Hanski and Korpimäki 1995; Turchin and Hanski 1997). These models attempt to be empirically based. Unfortunately, many of the assumptions entering these more refined models are not tested, and the parameters are generally not formally estimated from data. The assumed parameter values are derived from a variety of populations and not from one particular population that the models are supposed to represent. In spite of these shortcomings, we encourage the developments of such models - not the least to serve as a supplement to the more general models of the Lotka-Volterra type, and to help interpret statistical results based on time series data.

These recent developments of mathematical modeling of periodically fluctuating microtine populations have generated a renewed interest among mathematical modelers in the development of refined models (Lindström 1993, 1994; Gyllenberg et al. 1997). This development is very encouraging, because proper mathematical work is carried out on models based on reasonable biological assumptions.

Essentially, all mathematical modeling of population cycles since the pioneering papers of Volterra (1931) and Lotka (1925) ignore stochasticity. Within this tradition, the focus has been - and still is - on non-linear structures in the ecological interactions. This bias is also apparent in much of the statistical analysis of time series data, which borrows concepts from the field of deterministic models (e.g. chaos as measured by the dominant Lyapunov exponent; see Turchin 1996) and thus ignores the fact that the data are generated by different stochastic processes, such as sampling variability, demographic, and environmental stochasticity (see, e.g. Falck et al. 1995b).

\section{Basic ecology meets applied ecology}

\footnotetext{
“Agronomists have for too long ignored ecology and the benefits from integrated research approaches. Ecologists have for too long considered agronomic systems inherently uninteresting. It's time to close the gap" (E. A. Paul and G. P. Robertson 1989:1596)
}

The Hokkaido data on the fluctuating abundance of the vole Clethrionomys rufocanus were originally obtained for the purpose of preventing damage to forestry plantations, through prediction of outbreaks and subsequent treatment (see Kaneko et al. 1998); the sampling program has been a typical applied ecological monitoring program. In those respects it has been of much help (see Kaneko et al. 1998).
In addition, as already pointed out, these data are likely to play a profound role in years to come within the field of basic ecology.

A good parallel exists in Fennoscandia (mainly Finland and Sweden) where part of the initial impetus for monitoring small mammals stemmed from the development of forestry and large-scale planting of conifers. Small mammals at peak densities may indeed have significant negative impacts on early forest stages (especially on seedlings; Larsson 1975; Hansson and Zejda 1977; Myllymäki 1979).

Kirkendall and Stenseth (1989) discussed the value of applied research with respect to basic research within a slightly different setting. Nevertheless, their message was the same: through applied programs, huge data-sets often of high quality - may be obtained, data which may later represent a gold mine for basic ecology. Indeed, we recommend ecologists to look into the files of the more applied institutes: much important data may be hidden there.

The analysis of such data from a more fundamental perspective may also convey valuable applied interest, besides forestry. Small mammals are the reservoirs of a large number of human pathogens (Henttonen et al. 1996; Saitoh and Takahashi 1998), and large-scale epidemiological studies now focus on small mammals distribution and dynamics (e.g. Niklasson et al. 1995). Recent studies stress the importance of spatial and social structure of the host population when aiming at predicting/limiting the risks to human health (e.g. Grenfell and Harwood 1997). Basic knowledge of dynamical patterns in Clethrionomys is most useful in this context.

\section{The study of population ecology - adopting a pluralistic approach}

\footnotetext{
"To demand that each step in the process be accompanied by rigorous field testing would bring a halt to the development of theory as surely as the demand that each experiment be accompanied by significant new theory would halt experimental research" (H. Caswell 1988: 39)
}

One characteristic of population ecology is its reliance on a variety of approaches and methods (McIntosh 1987; Fig. 2). Population ecology has greatly benefited from developments in various other fields (e.g. statistics, genetics) and has provided fruitful challenges for the development of these disciplines. Population ecology of small mammals is by no means an exception, as has been emphasized above. The complexity and diversity in the tools used has a cost: it makes the integration of different types of knowledge difficult (Fig. 2). It invites criticisms stemming from the fact that models are either too simple (e.g. to 
realistically describe ecological relationships) or too complex (e.g. to allow for mathematical or statistical analyses). It also makes it difficult to compare results obtained using different study designs (e.g. observational and experimental studies), often conducted at different scales and with reference to different species.

We think that the population ecology of the gray-sided vole in Hokkaido may provide a fertile ground for integrating different approaches, mainly because a large number of time series of population abundance have already been acquired. They provide unique opportunities for detailed analyses of patterns at a large scale. As pointed out above, such data are typical of survey programs (Kish 1987): they were acquired to monitor abundance of small mammals without any aim of understand- ing the mechanisms causing variation in abundance. There were no hypothesis to be tested, only a trial effort at building a predictive tool based on observed abundance. They may later on be used for testing hypotheses; but their main goal is to be representative (through adequate sampling designs) of the phenomenon of interest (Ims and Yoccoz 1998). Experimental studies - involving manipulation and randomization - have opposite characteristics (Fig. 2): they explicitly test some hypotheses, but do not usually aim at being representative of a 'population' and may suffer from a lack of realism (e.g. the fence effect described by Krebs et al. (1969); see also Krebs (1992)). Experimental studies control as much as is possible the factor of interest (usually by specifying some $a$ priori levels) and 'control' other factors by using randomization

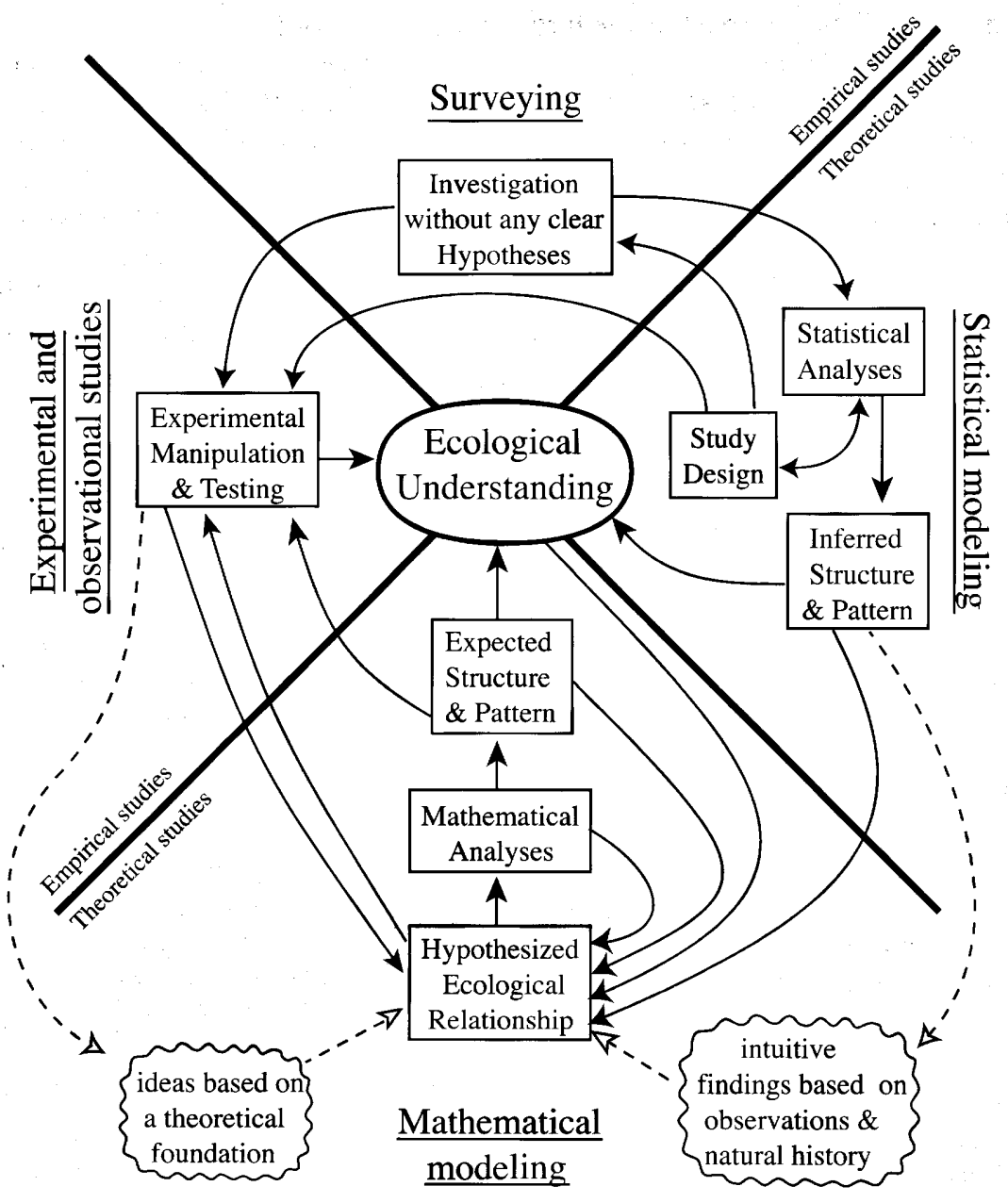

Fig. 2. Gaining knowledge on population fluctuations of small mammals as a pluralistic process. No single approach can be claimed to be sufficient - all are necessary: surveys are needed as part of the description of the natural patterns ("what?"), experimental and observational studies aim at evaluating the importance of specific mechanisms (both questions on "why?" and "how?"), statistical methods - dealing with design and analysis - are crucial because of the large intrinsic variability of ecological phenomena at various scales ("how?"), and mathematical methods formalize the link between hypothesized mechanisms and observed patterns. Work done on Clethrionomys rufocanus at Hokkaido illustrates these different but complementary approaches. 
(Fisher 1935; Kish 1987; Ims and Yoccoz 1998). Observational studies may also aim at testing some hypotheses, but are weaker than experimental studies on the controlling side. They may, however, be stronger than experimental studies on the realism side. Each type of study has lead to the development of specific statistical methods (surveys: Kish 1987; Thompson 1997; experiments: Fisher 1935; Cox 1958; Atkinson 1996: observational studies: Anderson et al. 1980; Rosenbaum 1995). Each approach has its strengths and weaknesses, and it is still unclear how a research program would most efficiently combine them. The fact that different approaches have often been used in North America (experimental studies: see Krebs 1988) and Fennoscandia (observational studies and surveys: see Hansson and Henttonen 1988) reflects partly this difficulty (see Hansson and Stenseth 1988; see also Haila 1982; Stenseth 1984).

A major obstacle to any pluralistic approach is the lack of common ground; e.g. theoretical models are often too complicated to be reliably fitted to any data-set, or do not state explicitly in biological terms the assumptions made. The following papers in this Special Feature show that a variety of approaches may be applied to the same ecological problem. Kaneko et al. (1998) and Ishibashi et al. (1998a, b) provide the basic building blocks, i.e. natural history and population biology of the gray-sided vole. Saitoh et al. (1998b) and Bjørnstad et al. (1998b) describe the dynamical patterns, both with respect to what we want to explain, and to possible mechanisms. Yoccoz et al. (1998) provide a framework linking ecological mechanisms, demography and population dynamics, while Stenseth et al. (1998b) show how a theoretical model may be used for interpreting obtained statistical results. Finally Saitoh and Takahashi (1998) show that such basic knowledge may be helpful to understand the dynamics of a human pathogen.

\section{The Special Feature on "The population ecol- ogy of the vole Clethrionomys rufocanus"}

\footnotetext{
"All ecologists favor long-term studies and in this respect differ from chemists, physicists, most other biologists, and all politicians. But, like other scientists, ecologists prefer to do experimental work. ... We must combine these two approaches to solve the major ecological questions." (C. J. Krebs 1991: 3)
}

The purpose of this Special Feature of Researches on Population Ecology is to bring together several results on the population ecology of $C$. rufocanus. We attempt to provide a synthesis of studies having used both the 'watch-and-count, wait-and-hope approach' and the 'muck-about-with-something approach' (see above).

We hope that the present Special Feature will be of general interest, not only to those researchers working on population cycles of small mammals, but more generally to those interested in the general issue of population dynamics and density-dependence. First of all, population cycles are not restricted to small mammals, but are known to exist in other mammals (Finerty 1980; Keith 1990; Clutton-Brock et al. 1997), in birds (Andreev 1988; Lindén 1988; Moss et al. 1996) and among insects (Tenow 1972; Myers 1988). Most importantly, the relevance of scale and space for ecological processes and the need for linking individual behavior and population ecology have been repeatedly stressed in recent years (e.g. Wiens 1989; Kareiva 1994; Sutherland 1996).

Several similar volumes have been published before, both on Clethrionomys (Petrusewicz 1983; Flowerdew et al. 1985; Stenseth 1985b) and on other microtine rodents (Stenseth 1977b; Tamarin 1985; Stenseth and Ims 1993c). This collection of papers is, however, different from the earlier ones in at least two respects: a single species is targeted and a large data-set is the focal point. We hope that this sharpness will provide the in-depth treatment typical of monographic treatises. If that is so, this Special Feature should most properly be considered a monograph on the $C$. rufocanus of Hokkaido.

This volume is also somewhat different from the others in that both theoretical and empirical approaches are adopted toward the study of the same species. As Lewontin (1968; cited from Caswell 1988: 35) remarked thirty years ago, these approaches do not aim at the same goal:

"Theoretical population biology is the science of the possible; only direct observation can yield a knowledge of the actual".

We hope that this Special Feature demonstrates that it is at the intersection between theoretical modeling and observations where we find new insights. It is our hope that we with this collection of paper have provided an improved platform for a variety of further studies using a variety of approaches.

Acknowledgments: Several agencies have made our work possible: For NCS: Norwegian Science Council (NFR) and University of Oslo as well as Centre for Advanced Study of the Norwegian Academy of Science and Letters. For TS: Forestry and Forest Products Research Institute of Japanese Government (FFPRI) and Centre for Advanced Study of the Norwegian Academy of Science and Letters. For NGY: the University of Lyon and the Centre National de la Recherche Scientifique (CNRS) in France. Furthermore, a grant from FFPRI brought NCS to Japan. We are indebted to Ottar N. Bjørnstad, Rolf A. Ims, Yoshiaki Itô, Fabian M. Jaksic, Romain Julliard, Kenji Fujisaki, Naoto Kamata, Mauricio Lima and Howell Tong for having discussed issues treated in this paper with us, for providing information used in this paper and/or for having commented on earlier versions of this paper. 


\section{References}

Abe, H. (1976) Population structure and reproductive activity of Clethrionomys rufocanus bedfordiae (Thomas) in a wind shelterbelt of the Ishikari Plain, Hokkaido. Journal of the Mammalogical Society of Japan 7: 17-30.

Albon, S. D., T. H. Clutton-Brock and F. E. Guiness (1987) Early development and population dynamics in red deer. II. Densityindependent effects and cohort variation. Journal of Animal Ecology 56: $69-81$.

Anderson, S., A. Auquier, W. W. Hauck, D. Oakes, W. Vandaele and H. I. Weisberg (1980) Statistical methods for comparative studies. John Wiley and Sons, New-York.

Andreev, A. (1988) The ten year cycle of the willow grouse of lower Kolyma. Oecologia 76: 261-267.

Andrewartha, H. G. and L. C. Birch (1954) The distribution and abundance of animals. University of Chicago Press, Chicago.

Andrewartha, H. G. and L. C. Birch (1984) The ecological web. University of Chicago Press, Chicago.

Atkinson, A. C. (1996) The usefulness of optimum experimental designs. Journal of the Royal Statistical Society B 58: 59-76.

Barbour, D. A. (1990) Synchronous fluctuations in spatially separated populations of cyclic forest insects. pp. 339-346. In A. D. Watt, S. R. Leather, M. D. Hunter and N. A. C. Kidd (eds.) Population dynamics of forest insects. Intercept, Andover, Hampshire.

Bartlett, M. S. (1970) Stochastic population models. Metheuen \& Co Ltd, London.

Batzli, G. O. (1996) Population cycles revisited. Trends in Ecology and Evolution 11: 488-489.

Berryman, A. A. (1991) Stabilization or regulation: what it all means! Oecologia 86: 140-143.

Berryman, A. A. (1992) Vague notions of density-dependence. Oikos 62: 252-254.

Bjørnstad, O. N., W. Falck and N. C. Stenseth (1995) A geographic gradient in small rodent density fluctuations: a statistical modelling approach. Proceedings of the Royal Society of London B 262: 127-133.

Bjørnstad, O. N., N. C. Stenseth and T. Saitoh (1998a) Synchrony and scaling in dynamics of voles and mice in northern Japan. Ecology (in press).

Bjørnstad, O. N., N. C. Stenseth, T. Saitoh and O. C. Lingjærde (1998b) Mapping the regional transition in dynamics of Clethrionomys rufocanus: spectral densities and functional data analysis. Researches on Population Ecology 40: 77-84.

Bjørnstad, O. N., M. Begon, N. C. Stenseth, W. Falck, S. M. Sait and D. J. Thompson (1998c) Population dynamics of the Indian meal moth: Demographic stochasticity and delayed regulatory mechanisms. Journal of A nimal Ecology 67: 110-126.

Bondrup-Nielsen, S. (1986) Investigation of spacing behaviour of Clethrionomys gapperi by experimentation. Journal of Animal Ecology 55: 269-280.

Box, J. F. (1978) R. A. Fisher, the life of a scientist. John Wiley and Sons, New York.

Bujalska, G. (1970) Reproduction stabilizing elements in an island population of Clethrionomys glareolus (Schreber, 1780). Acta Theriologica 15: 381-412.

Cappuccino, N. and P. W. Price (1995) Population dynamics. Academic Press, New York.

Campbell, M. J. and A. M. Walker (1977) A survey of statistical work on the Mackenzie River series of annual Canadian lynx trappings for the years 1821-1934 and a new analysis. Journal of the
Royal Statistical Society A 140: 411-431 and 448-468.

Caswell, H. (1988) Theory and models in ecology: a different perspective. Ecological Modelling 43: 33-44.

Chan, K.-S., H. Tong and N. C. Stenseth (1998a) Analyzing abundance data from periodically fluctuating rodent populations by threshold models: a nearest neighbour bootstrap approach. (in review).

Chan, K.-S., H. Tong and N. C. Stenseth (1998b) Testing for common structure in a panel of threshold models. (in review).

Charnov, E. L. and J. P. Finerty (1980) Vole population cycles: a case for kin-selection? Oecologia 45: 1-2.

Chitty, D. (1960) Population processes in the vole and the relevance to general theory. Canadian Journal Zoology 38: 99-113.

Chitty, D. (1967) The natural selection of self-regulatory behaviour in animal populations. Proceedings of Ecological Society of Australia 2: 51-78.

Christian, J. J. (1950) The andro-pituitary system and population cycles in small mammals. Journal of Mammalogy 31: 247-259.

Christian, J. J. (1980) Endocrine factors in population regulation. pp. 55-115. In M. N. Cohen, R. S. Malpass and H. G. Klein (eds.) Biosocial mechanisms of population regulation. Yale University Press, New Haven.

Clutton-Brock, T. H., M. Major and F. E. Guinness (1985) Population regulation in male and female red deer. Journal of Animal Ecology 54: 831-846.

Clutton-Brock, T. H., O. F. Price, S. D. Albon and P. A. Jewell (1991) Persistent instability and population regulation in Soay sheep. Journal of Animal Ecology 60: 593-608.

Clutton-Brock, T.H., A.W. Illius, K. Wilson, B. T. Grenfell, A. D. C. MacColl and S. D. Albon (1997) Stability and instability in ungulate populations: an empirical analysis. American Naturalist 149: 195-219.

Cockburn, A. (1988) Social behavior in fluctuating populations. Croom Helm, London.

Collett, R. (1911/1912) Norges pattedyr (Norwegian mammals). Aschehoug and Company, Kristiania (in Norwegian).

Cox, D. R. (1958) Planning of experiments. John Wiley and Sons, New York.

Crowcroft, P. (1991) Elton's ecologist. A history of the bureau of animal populations. The University of Chicago Press, Chicago.

Crowley, P. H. (1992) Density dependence, boundedness, and attraction: detecting stability in stochastic systems. Oecologia 90: 246-254.

de Roos, A. M., E. McCauley and W. G. Wilson (1991) Mobility versus density-limited predator-prey dynamics on different spatial scales. Proceedings of the Royal Society of London B 246: 117122.

Den Boer, P. J. (1991) Seeing the trees for the wood: random walks or bounded fluctuations of population size? Oecologia 86: 484491.

Den Boer, P. J. and J. Reddingius (1996) Regulation and stabilization paradigms in population ecology. Chapman and Hall, London.

Dennis, B. and G. P. Patil (1984) The gamma distribution and weighted multimodal gamma distribution as models of population abundance. Mathematical Biosciences 68: 187-212.

Dennis, B., R. A. Desharnais, J. M. Cushing and R. F. Costantino (1997) Transitions in population dynamics: Equilibria to periodic cycles to aperiodic cycles. Journal of Animal Ecology 66: 704-729.

Eberhardt, L. L. (1977) Optimal management policies for marine mammals. Wildlife Society Bulletin 5: 162-169.

Ellner, S. and P. Turchin (1995) Chaos in noisy world: new methods and evidence from time-series analysis. American Naturalist 154: 
343-375.

Elton, C. S. (1924) Periodic fluctuations in the numbers of animals: their causes and effects. Journal of Experimental Biology 2: 119163.

Elton, C. S. (1942) Vole, mice and lemmings. Clarendon Press, Oxford.

Engen, S. and R. Lande (1996) Population dynamic models generating the lognormal species abundance distribution. Mathematical Biosciences 132: 169-183.

Epperson, B. K. and T.Q. Li (1997) Gene dispersal and spatial genetic structure. Evolution 51: 672-681.

Falck, W., O. N. Bjørnstad and N. C. Stenseth (1995a) Bootstrap estimated uncertainty of the dominant Lyapunov exponent for Holarctic microtine rodents. Proceedings of the Royal Society of London B 261: 159-165.

Falck, W., O. N. Bjørnstad and N. C. Stenseth (1995b) Voles and lemmings. Chaos and uncertainty in fluctuating populations. Proceedings of the Royal Society of London B 262: 363-370.

Finerty, J.P. (1980) The population ecology of cycles in small mammals: Mathematical theory and biological fact. Yale University Press, New Haven.

Fisher, R. A. (1935) The design of experiments. Oliver and Boyd, Edinburgh.

Flowerdew, J. R., J. Gurnell and J. H. W. Gipps (1985) The ecology of woodland rodents bank voles and wood mice. Zoological Society of London Symposia 55, Clarendon Press, Oxford.

Framstad, E., N. C. Stenseth, O. N. Bjørnstad and W. Falck (1997) Limit cycles in Norwegian lemmings: tensions between phasedependence and density-dependence. Proceedings of the Royal Society of London B 264: 31-38.

Gaillard, J.-M. and N. G. Yoccoz (1998) Adaptive responses of juvenile and adult survival to environmental variation in mammalian populations. (in review).

Gaillard, J.-M., M. Festa-Bianchet and N. G. Yoccoz (1998) Population dynamics of large herbivores: variable recruitment with constant adult survival. Trends in Ecology and Evolution 13: 58-63.

Gaillard, J.-M., D. Delorme, J.-M. Boutin, G. van Laere, B. Boisaubert and R. Pradel (1993) Roe deer survival patterns: a comparative analysis of contrasting populations. Journal of Animal Ecology 62: 778-791.

Gaines, M. S., N. C. Stenseth, M. L. Johnson, R. A. Ims and S. Bondrup-Nielsen (1991) A response to solving the enigma of population cycles with a multifactorial perspective. Journal of Mammalogy 72: 627-631.

Gilbert, B. S., C. J. Krebs, D. Talarico and D. B. Cichowski (1986) Do Clethrionomys rutilus females suppress maturation of juvenile females? Journal of Animal Ecology 55: 543-552.

Gilbert, N. (1984) What they didn't tell you about limit cycles. Oecologia 65: 112-113.

Grenfell, B. and J. Harwood (1997) (Meta)population dynamics of infectious diseases. Trends in Ecology and Evolution 12: 395-399.

Grenfell, B. T., O. F. Price, S. D. Albon and T. H. Clutton-Brock (1992) Overcompensation and population cycles in an ungulate. Nature 355: 823-826.

Gromov, I. M. and I. Ya. Plyakov (1992) Voles (Microtinae). Fauna of the USSR; Mammals 3(8).

Gustafsson, T.O. (1985) Sexual maturation in Clethrionomys. Annales Zoologici Fennici 22: 303-308.

Gyllenberg, M., I. Hanski and T. Lindström (1997) Continuous versus discrete single species population models with adjustable reproductive strategies. Bulletin of Mathematical Biology 59: 679705.

Haila, Y. (1982) Hypothetico-deductivism and the competition con- troversy in ecology. Annales Zoologici Fennici 19: 255-263.

Haila, Y. and O. Järvinen (1982) The role of theoretical concepts in understanding the ecological theater: a case study on island biogeography. pp. 261-278. In E. Saarinen (ed.) Conceptual issues in ecology. D Reidel, Dordrecht, The Netherlands.

Hanski, I. (1990) Density dependence, regulation and variability in animal populations. pp. 140-150. In R. M. May and M. P. Hassell (eds.) Regulation and relative abundance of plants and animals. The Royal Society, London.

Hanski, I. and E. Korpimäki (1995) Microtine rodent dynamics in northern Europe: parameterized models for the predator-prey interaction. Ecology 76: 840-850.

Hanski, I., L. Hansson and H. Henttonen (1991) Specialist predators, generalist predators, and the microtine rodent cycle. Journal of Animal Ecology 60: 353-367.

Hanski, I., I. P. Woiwod and J. Perry (1993) Density dependence, population persistence, and largely futile arguments. Oecologia 95: 595-598.

Hansson, L. (1971) Habitat, food and population dynamics of the field vole Microtus agrestis (L.) in Southern Sweden. Viltrevy 8: 267-378.

Hansson, L. (1979) On the importance of landscape heterogeneity in northern region for the breeding population densities of homeotherms: a general hypothesis. Oikos 33: 182-189.

Hansson, L. (1987) Vole sex ratios: the importance of mating systems and maternal condition. Oikos 49: 161-164.

Hansson, L. and H. Henttonen (1985) Gradients in density variations of small rodents: the importance of latitude and snow cover. Oecologia 67: 394-402.

Hansson, L. and H. Henttonen (1988) Rodent dynamics as community processes. Trends in Ecology and Evolution 3: 195-200.

Hansson, L. and N. C. Stenseth (1988) Modelling small rodent population dynamics: suggestions to empiricists, theoreticians and editors. Oikos 52: 227-229.

Hansson, L. and J. Zejda (1977) Plant damage by bank voles (Clethrionomys glareolus, Schreber) and related species in Europe. EPPO Bulletin 7: 223-242.

Hassell, M. P., J. Latto and R. M. May (1989) Seeing the wood for the trees: detecting density dependence from testing life table studies. Journal of Animal Ecology 58: 883-892.

Haukioja, E., S. Neuvonen, S. Hanhimäki and P. Niemelä (1988) The autumnal moth in Fennoscandia. pp. 163-177. In A. A. Berryman (ed.) Dynamics of forest insect populations: patterns, causes, and management strategies. Plenum Press, New York.

Henttonen, H. and A. Kaikusalo (1993) Lemming movement. pp. 157-186. In N. C. Stenseth and R. A. Ims (eds.) The biology of lemming. Academic Press, London.

Henttonen, H., A. D. McGuire and L. Hansson (1985) Comparisons of amplitudes and frequencies (spectral analyses) of density variations in long-term data sets of Clethrionomys species. Annales Zoologici Fennici 22: 221-227.

Henttonen, H., O. Vapalahti and A. Vaheri (1996) How many kinds of hantaviruses? Trends in Ecology and Evolution 11: 7-8.

Hestbeck, J. B. (1982) Population regulation of cyclic mammals: the social fence hypothesis. Oikos 39: 157-163.

Hjellvik, V. and D. Tjøstheim (1998a) Modeling panels of intercorrelated autoregressive time series (in review).

Hjellvik, V. and D. Tjøstheim (1998b) Residual variance estimation and order determination in panels of intercorrelated autoregressive time series (in review).

Holyoak, M. (1994) Appropriate time scales for identifying lags in density-dependent processes. Journal of Animal Ecology 63: 479483. 
Hörnfeldt, B. (1994) Delayed density dependence as a determinant of vole cycles. Ecology 75: 791-806.

Ims, R. A. (1988) Spatial clumping of sexually receptive females induces space sharing among male voles. Nature 335: 541-543.

Ims, R. A. (1994) Litter sex ratio variation in laboratory colonies of two geographically distinct strains of the root vole Microtus oeconomus. Ecography 17: 141-146.

Ims, R. A. (1997) Determinants of geographic variation in growth and reproductive traits in the root vole. Ecology 78: 461-470.

Ims, R. A. and H. Steen (1990) Geographical synchrony in microtine population cycles: a theoretical evaluation of the role of nomadic predators. Oikos 57: 381-387.

Ims, R. A. and N. G. Yoccoz (1998) Ecological methodology: study design and statistical analysis. Technical Report, University of Oslo.

Ishibashi, Y., T. Saitoh, S. Abe and M. C. Yoshida (1997) Sexrelated spatial kin structure in a spring population of grey-sided voles Clethrionomys rufocanus as revealed by mitochondrial and microsatellite DNA analyses. Molecular Ecology 6: 63-71.

Ishibashi, Y., T. Saitoh and M. Kawata (1998a) Social organization of the vole Clethrionomys rufocanus and its demographic and genetic consequences: a review. Researches on Population Ecology 40: $39-50$.

Ishibashi, Y., T. Saitoh, S. Abe and M. C. Yoshida (1998b) Kinrelated social organization in a winter population of the vole Clethrionomys rufocanus. Researches on Population Ecology 40: 51-59.

Itô, Y. (1968) Are insect populations periodically fluctuating? Kagaku (Science) 38: 39-45 (in Japanese).

Itô, Y. (1978) Comparative ecology, 2nd edn. Iwanami-shoten, Tokyo. (in Japanese) English version (edited and translated by J. Kikkawa) was published in 1980. Cambridge University Press, Cambridge.

Kalela, O. (1957) Regulation of reproduction rate in subarctic populations of the vole Clethrionomys rufocanus (Sund.). Annales Academiae Scientiarum Fennicae, Series A IV, Biologica 34: 1-60.

Kaneko, Y., K. Nakata, T. Saitoh, N. C. Stenseth and Ottar N. Bjørnstad (1998) The biology of the vole Clethrionomys rufocanus: a review. Researches on Population Ecology 40: 21-37.

Kareiva, P. (1994) Space: the final frontier for ecological theory. Ecology 75: 1.

Kawata, M. (1997) Exploitative competition and ecological effective abundance. Ecological Modelling 94: 125-137.

Keith, L. B. (1990) Dynamics of snowshoe hare populations. Current Mammalogy 2: 119-195.

Kendall, D. G. (1949) Stochastic processes and population growth. Journal of the Royal Statistical Society B 11: 230-264.

Kirkendall, L. and N. C. Stenseth (1989) Population dynamics of bark beetles, with special reference to Ips typographus: contributions of applied bark beetle studies to basic research in ecology and population biology. Holarctic Ecology 12: 526-527.

Kish, L. (1987) Statistical design for research. John Wiley and Sons, New York.

Klimertzek, D. (1990) Population dynamics of pine-feeding insects: a historical study. pp. 3-10. In A. D. Watt, S. R. Leather, M. D. Hunter and N. A. C. Kidd (eds.) Population dynamics of forest insect. Intercept, Andover, UK.

Krebs, C. J. (1978) A review of the Chitty hypothesis of population regulation. Canadian Journal of Zoology 56: 2463-2480.

Krebs, C. J. (1988) The experimental approach to rodent population dynamics. Oikos 52: 143-149.

Krebs, C. J. (1991) The experimental paradigm and long-term population studies. Ibis 133 supplement 1: $3-8$.
Krebs, C. J. (1992) The role of dispersal in cyclic rodent populations. pp. 160-175. In N. C. Stenseth and W. Z. Lidicker (eds.) Animal dispersal: small mammals as a model. Chapman and Hall, London.

Krebs, C. J. (1994) Ecology: The experimental analysis of distribution and abundance, 4th edn. Harper Collins College Publishers, New York.

Krebs, C. J. (1996) Population cycles revised. Journal of Mammalogy 77: 8-24.

Krebs, C. J. (1997) Vole cycle on Hokkaido: a time-series goldmine. Trends in Ecology and Evolution 12: 340-341.

Krebs. C. J. and J. H. Myers (1974) Population cycles in small mammals. Advances in Ecological Research 8: 267-299.

Krebs, C. J., B. L. Keller and R. H. Tamarin (1969) Microtus population biology: demographic changes in fluctuating populations of $M$. ochrogaster and $M$. pennsylvanicus in southern Indiana. Ecology 50: $587-607$.

Krebs, C. J., S. Boutin, R. Boonstra, A. R. E. Sinclair, J. N. M. Smith, M. R. T. Dale, K. Martin and R. Turkington (1995) Impact of food and predation on the snowshoe hare cycle. Science 269: 112-115.

Lack, D. (1954) The natural regulation of animal numbers. Oxford University Press.

Lambin, X. and C. J. Krebs (1991) Can changes in female relatedness influence microtine population dynamics? Oikos 61: 126-132.

Lambin, X. and C. J. Krebs (1993) Influence of female relatedness on the demography of Townsend's vole populations in spring. Journal of Animal Ecology 62: 536-550.

Lambin, X. and N. G. Yoccoz (1998) The impact of population kin-structure on nestling survival in Townsend's voles, Microtus townsendii. Journal of Animal Ecology 67: 1-16.

Lambin, X., D. Elston, S. Petty and J. L. MacKinnon (1998) Spatial asynchrony and periodic travelling waves in cyclic populations of field vole. Proceedings of the Royal Society of London B (in press).

Larsson, T.-B. (1975) Damage caused by small rodents in Sweden. Ecological Bulletins 19: 163-173.

Lebreton, J.-D. (1990) Modelling density dependence, environmental variability, and demographic stochasticity from population counts: An example using Wytham Wood great tits. pp. 89-102. In J. Blondel, A. Gosler, J.-D. Lebreton and R. McCleery (eds.) Population biology of the passerine birds. Springer-Verlag, Berlin.

Lebreton, J. D., K. P. Burnham, J. Clobert and D. R. Anderson (1992) Modeling survival and testing biological hypotheses using marked animals: a unified approach with case studies. Ecological Monographs 62: 67-118.

Leirs, H., N. C. Stenseth, J. D. Nichols, J. E. Hines, R. Verhagen and W. Verheyen (1997) Stochastic seasonality and nonlinear density-dependent factors regulate population size in an African rodent. Nature 389: 176-180.

Lewontin, R. C. (1968) Population biology and evolution. Syracuse University Press, Syracuse.

Lidicker, W. Z., Jr. (1988) Solving the enigma of the microtine 'cycle'. Journal of Mammalogy 69: 225-235.

Lidicker, W. Z., Jr. (1991) In defense of a multifactor perspective in population ecology. Journal of Mammalogy 72: 636-635.

Liebhold, A., N. Kamata and T. Jacob (1996) Cyclicity and synchrony of historical outbreaks of the beech caterpillar, Quadricalcarifera punctatella (Motschulsky) in Japan. Researches on Population Ecology 38: 87-94.

Lindén, H. (1988) Latitudinal gradients in predator-prey interactions, cyclicity and synchronism in voles and small game populations in Finland. Oikos 52: 341-349.

Lindström, T. (1993) Qualitative analysis of a predator-prey system 
with limit cycles. Journal of Mathematical Biology 31: 541-561.

Lindström, T. (1994) Global stability of a model for competing predators. pp. 233-245 In M. Gyllenberg and L.-E. Persson (eds.) Analysis, algebra, and computers in mathematical research. Marcel Dekker, New York.

Loreto, V., G. Paladin and A. Vulpiani (1996) Concept of complexity in random dynamical systems. Physical Review E 53: 20872098.

Lotka, A. J. (1925) Elements of physical biology. Williams \& Wilkins, Baltimore.

May, R. M. (1972) Limit cycles in predator-prey communities. Science 177: 900-902.

May, R. M. (1974) Biological populations with nonoverlapping populations: stable points, stable cycles, and chaos. Science 186: 645-647.

May, R. M. (1986) When two and two do not make four: nonlinear phenomena in ecology. Proceedings of the Royal Society of London B 228: 241-266.

Maynard Smith, J. (1982) Storming the fortress. New York Review May 13, 1982: 41-42.

McIntosh, R. P. (1987) Pluralism in ecology. Annual Review of Ecology and Systematics 18: 321-341.

Messier, F. (1991) The significance of limiting and regulating factors on the demography of moose and white-tailed deer. Journal of Animal Ecology 60: 377-393.

Moran, P. A. P. (1953a) The statistical analysis of the Canadian lynx cycle. I structure and prediction. Australian Journal of Zoology 1: 163-173.

Moran, P. A. P. (1953b) Statistical analysis of the Canadian Lynx cycle, 2. Synchronization and meteorology. Australian Journal of Zoology 1: 291-298.

Moss, R., A. Watson and R. Parr (1996) Experimental prevention of population cycle in red grouse. Ecology 77: 1512-1530.

Murdoch, W. W. (1994) Population regulation in theory and practice. Ecology 75: 271-287.

Myers, J. H. (1988) Can a general hypothesis explain population cycles of forest Lepidoptera? Advances in Ecological Research 18: 179-242.

Myers, J. H. (1998) Synchrony in outbreaks of forest Lepidoptera: a possible example of the Moran effect. Ecology 79: 1111-1117.

Myllymäki, A. (1979) Importance of small mammals as pests in agriculture and stored products. pp. 239-279. In D. M. Stoddart (ed.) Ecology of small mammals. Chapman and Hall, London.

Nakata, K. (1989) Regulation of reproduction rate in a cyclic population of the red-backed vole, Clethrionomys rufocanus bedfordiae. Researches on Population Ecology 31: 185-209.

Nicholson, A. J. (1933) The balance of animal populations. Journal of Animal Ecology Supplement 2: 132-178.

Nicholson, A. J. (1954) An outline of the dynamics of animal populations. Australian Journal of Zoology 2: 9-65.

Niklasson, B., B. Hörnfeldt, A. Lundkvist, S. Bjorsten and J. Leduc (1995) Temporal dynamics of Puumula virus antobody prevalence in voles and nephropathia epidemica incidence in humans. American Journal of Tropical Medicine and Hygiene 53: 134-140.

Ostfeld, R. S., C. D. Canham and S. R. Pugh (1993) Intrinsic density-dependent regulation of vole populations. Nature 366: 259261.

Ostfeld, R. S. and C. D. Canham (1995) Density-dependent processes in meadow voles: an experimental approach. Ecology 76: 521532.

Paladin, G., M. Serva and A. Vulpiani (1995) Complexity in dynamical systems with noise. Physical Review Letters 74: 66-69.

Paul, E. A. and G. P. Robertson (1989) Ecology and the agricultural sciences: a false dichotomy? Ecology 70: 1594-1597.

Petrusewicz, K. (ed.) (1983) Ecology of the bank vole. Acta Theriologica 28 Supplement 1.

Pitelka, F. A. and G. O. Batzli (1993) Distribution, abundance and habitat use by lemmings on the north slope of Alaska. pp. 213-236. In N. C. Stenseth and R. A. Ims (eds.) The biology of lemming. Academic Press, London.

Pollock, K. H., J. D. Nichols, C. Brownie and J. E. Hines (1990) Statistical inference for capture-recapture experiments. Wildlife Monographs 107: 1-97.

Portier, C., M. Festa Bianchet, J.-M. Gaillard, J. T. Jorgenson and N. G. Yoccoz (1998) Effects of density and weather on survival of bighorn sheep lambs (Ovis canadensis). Journal of Zoology, London (in press).

Ranta, E. and V. Kaitala (1997) Travelling waves in vole population dynamics. Nature 390: 456.

Ranta, E., V. Kaitala and P. Lundberg (1997) The spatial dimension in population fluctuations. Science 278: 1621-1623.

Rosenbaum, P. R. (1995) Observational studies. Springer-Verlag, New York.

Royama, T. (1992) Analytical population dynamics. Chapman and Hall, London.

Ruxton, G. D. and M. Doebeli (1996) Spatial self-organization and persistence of transients in a metapopulation model. Proceedings of the Royal Society of London B 263: 1153-1158.

Saitoh, T. (1981) Control of female maturation in high density populations of the red-backed vole, Clethrionomys rufocanus bedfordiae. Journal of Animal Ecology 50: 79-87.

Saitoh, T. (1991) The effects and limits of territoriality on population regulation in grey red-backed voles, Clethrionomys rufocanus bedfordiae. Researches on Population Ecology 33: 367-386.

Saitoh, T. and K. Takahashi (1998) The role of vole populations in prevalence of the parasite (Echinococcus multilocularis) in foxes. Researches on Population Ecology 40: 97-105.

Saitoh, T., N. C. Stenseth and O. N. Bjørnstad (1997) Density dependence in fluctuating grey-sided vole populations. Journal of Animal Ecology 66: 14-24.

Saitoh, T., O. N. Bjørnstad and N. C. Stenseth (1998a) Densitydependence in voles and mice: a comparative study. Ecology (in press).

Saitoh, T., N. C. Stenseth and O. N. Bjørnstad (1998b) The population dynamics of the vole Clethrionomys rufocanus in Hokkaido, Japan. Researches on Population Ecology 40: 61-76.

Saucy, F. (1994) Density dependence in time series of the fossorial form of the water vole, Arvicola terrestris. Oikos 71: 381-392.

Sauer, J.R. and M.S. Boyce (1983) Density dependence and survival of elk in Northwestern Wyoming. Journal of Wildlife Management 47: 31-37.

Seber, G. A. F. (1992) A review of estimating animal abundanice II. International Statistical Review 60: 129-166.

Shigesada, N. and K. Kawasaki (1997) Biological invasions: theory and practice. Oxford University Press, Oxford.

Sinclair, A. R. E. (1989) Population regulation in animals. pp. 197 241. In J. M. Cherrett (ed.) Ecological concepts. Blackwell Scientific Publications, Oxford.

Sinclair, A. R. E. and R. P. Pech (1996) Density dependence, stochasticity, compensation and predator regulation. Oikos 75: 164-173.

Sittler, B. (1995) Response of stoats (Mustela erminea) to a fluctuating lemming (Dicrostonyx groenlandicus) population in north east Greenland: preliminary results from a long-term study. Annales Zoologici Fennici 32: 79-92.

Sokal, R. R. and N. L. Oden (1978) Spatial autocorrelation in biol- 
ogy. I methodology, II application. Biological Journal of the Linnean Society 10: 199-228.

Stacy, J. E., P. E. Jorde, H. Steen, R. A. Ims, A. Purvis and K. S. Jakobsen (1997) Lack of concordance between mtDNA gene flow and population density fluctuations in the bank vole. Molecular Ecology 6: 751-759.

Steen, H. (1994) Low survival of long distance dispersers of the root vole (Microtus oeconomus). Annales Zoologici Fennici 31: 271274.

Steen, H., R. A. Ims and G. A. Sonerud (1996) Spatial and temporal patterns of small-rodent population dynamics at a regional scale. Ecology 77: 2365-2372.

Stenseth, N. C. (1977a) Evolutionary aspects of demographic cycles: the relevance of some models of cycles for microtine fluctuations. Oikos 29: 525-538.

Stenseth, N. C. (ed.) (1977b) Population dynamics of the field vole Microtus agrestis: a modelling study. Oikos 29: 445-641.

Stenseth, N. C. (1981) On Chitty's theory for fluctuating populations: the importance of polymorphisms in the generation of regular cycles. Journal of theoretical Biology 90: 9-36.

Stenseth, N. C. (1984) Why mathematical models in evolutionary ecology? pp. 239-267. In J. Cooley and F. B. Golley (eds.) Trends in ecological research of the 1980's. Plenum Press, New-York.

Stenseth, N.C. (1985a) Models of bank vole and wood mouse populations. Symposium of the Zoological Society of London 55: 339-376.

Stenseth, N. C. (ed.) (1985b) Clethrionomys biology: population dynamics, dispersal, reproduction and social structure. Annales Zoologici Fennici vol. 22, No. 3.

Stenseth, N. C. (1986) On the interaction between stabilizing social factors and destabilizing trophic factors in small rodent populations. Theoretical Population Biology 29: 365-384.

Stenseth, N. C. (1995a) The long-term study of voles, mice and lemmings: homage to Robert Collett. Trends in Ecology and Evolution 10: 512 .

Stenseth, N. C. (1995b) Snowshoe hare populations: squeezed from below and above. Science 269: 1061-1062.

Stenseth, N. C. and R. A. Ims (1993a) The history of lemming research: from the Nordic Sagas to The Biology of Lemmings. pp. 3-34. In N. C. Stenseth and R. A. Ims (eds.) The biology of lemming. Academic Press, London.

Stenseth, N. C. and R. A. Ims (1993b) Population dynamics of lemmings: temporal and spatial variation - an introduction. pp. 61-96. In N. C. Stenseth and R. A. Ims (eds.) The biology of lemming. Academic Press, London.

Stenseth, N. C. and R. A. Ims (eds.) (1993c) The biology of lemming. Academic Press, London.

Stenseth, N. C. and A. Lomnicki (1990) On the Charnov-Finerty hypothesis: the unproblematic transition from docile to aggressive and the problematic transition from aggressive to docile. Oikos 58: 234-238.

Stenseth, N. C., O. N. Bjørnstad and T. Saitoh (1996a) A gradient from stable to cyclic populations of Clethrionomys rufocanus in Hokkaido, Japan. Proceedings of the Royal Society of London B 263: $1117-1126$

Stenseth, N. C., O. N. Bjørnstad and W. Falck (1996b) Is spacing behaviour coupled with predation causing the microtine density cycle? A synthesis of process-oriented and pattern-oriented studies. Proceedings of the Royal Society of London B 263: 1423-1435.

Stenseth, N. C., W. Falck, O. N. Bjørnstad and C. J. Krebs (1997) Population regulation in snowshoe hare and lynx populations: asymmetric food web configurations between the snowshoe hare and the lynx. Proceedings of the National Academy of Science of the USA 94: 5147-5152.

Stenseth, N. C. R. Boonstra, N. G. Yoccoz and C. J. Krebs (1998a) Population cycles in lemmings and voles: dynamics and demographic signatures of non-linearity. (in review).

Stenseth, N. C., O. N. Bjørnstad and T. Saitoh (1998b) Seasonal forcing on the dynamics of Clethrionomys rufocanus: modelling the geographic gradient in population dynamics Researches on Population Ecology 40: 85-95.

Stenseth, N. C., W. Falck, K. S. Chan, O. N. Bjørnstad, M. O'Donoghue, H. Tong, R. Boonstra, S. Boutin, C. J. Krebs and N. G. Yoccoz (1998c) From ecological patterns to ecological processes: phase- and density-dependencies in the Canadian lynx cycle. (in review).

Stenseth, N. C., K.-S. Chan, E. Framstad and H. Tong (1998d) Phase- and density dependency dynamics in lemming populations: statistical and mathematical modelling of periodic temporal fluctuations with a fixed periodic component sustained by environmental stochasticity. (in review).

Stiling, P. (1988) Density-dependent processes and key factors in insect populations. Journal of Animal Ecology 57: 581-594.

Strong, D. (1986) Density-vague population change. Trends in Ecology and Evolution 1: 39-42.

Sugihara, G. (1994) Nonlinear forecasting for the classification of natural time series. Philosophical Transactions of the Royal Society of London A 348: 477-495.

Sutherland, W. J. (1996) From individual behaviour to population ecology. Oxford University Press, Oxford.

Sæther, B.-E. (1997) Environmental stochasticity and population dynamics of large herbivores: a search for mechanisms. Trends in Ecology and Evolution 12: 143-149.

Taitt, M. J. and C. J. Krebs (1985) Population dynamics and cycling. pp. 567-620. In R. H. Tamarin (ed.) Biology of New World Microtus. Special Publication of the American Society of Mammalogists, No. 8.

Tamarin, R. H. (ed.) (1985) Biology of New World Microtus, The American Society of Mammalogists, No. 8.

Tenow, O. (1972) The outbreaks of Oporinia autumnata Bkh. and Operophtera spp. (Lep., Geomtridae) in the Scandinavian mountain chain and northern Finland 1862-1968. Zoologiska Bidrag från Uppsala, Supplement 2: 1-107.

Thompson, M. E. (1997) Theory of sample surveys. Chapman and Hall, London.

Tjøstheim, D. (1994) Non-linear time series: a selective review. Scandinavian Journal of Statistics 21: 97-130.

Tong, H. (1977) Some comments on the Canadian lynx data with discussion. Journal of the Royal Statistical Society A 140: 432-435 and 448-468.

Tong, H. (1990) Non-linear time series: a dynamical system approach. Oxford University Press.

Tong, H. (1995) A personal overview of non-linear time series analysis from a chaos perspective. Scandinavian Journal of Statistics 22: 399-421.

Turchin, P. (1990) Rarity of density dependence or regulation with lags? Nature 344: 660-663.

Turchin, P. (1993) Chaos and stability in rodent population dynamics: evidence from non-linear time-series analysis. Oikos 68: 167172.

Turchin, P. (1995a) Population regulation: old arguments and a new synthesis. pp. 19-40. In N. Cappuccino and P. Price (eds.) Population dynamics. Academic Press, New York.

Turchin, P. (1995b) Chaos in microtine populations. Proceedings of the Royal Society of London B 262: 357-361.

Turchin, P. (1996) Nonlinear time-series modeling of vole popula- 
tion fluctuations. Researches on Population Ecology 38: 121-132.

Turchin, P. and I. Hanski (1997) An empirically based model for latitudinal gradient in vole population dynamics. American Naturalist 149: 842-874.

Volterra, V. (1931) Leçons sur la théorie mathématique de la lutte pour la vie. Marcel Brelot, Paris.

Vulpiani, A. (1995) On the effect of the noise in dynamical systems. Il nuovo cimento 17: 653-660.

Warkowska-Dratnal, H. and N. C. Stenseth (1985) Dispersal and the microtine cycle: comparison of two hypotheses. Oecologia 65: 468477.

Wiens, J. A. (1989) Spatial scaling in ecology. Functional Ecology 3: 385-397.

Woiwod, I. P. and I. Hanski (1992) Patterns of density dependence in moth and aphids. Journal of Animal Ecology 61: 619-629.

Yao, Q., H. Tong, B. Finkenstäd and N. C. Stenseth (1998) Common structure in panels of short time series. (in review).

Yoccoz, N. G., K. Nakata, N. C. Stenseth and T. Saitoh (1998) The demography of the vole Clethrionomys rufocanus: from mathematical and statistical models to further field studies. Researches on Population Ecology 40: 107-121.

Yule, G. U. (1927) On a method of investigating periodicities in disturbed series with special reference to Wolfer's sunspot numbers. Philosophical Transactions of the Royal Society of London A 226: 267-98.

Received 12 May 1998; Accepted 29 May 1998 